\title{
IMPRESSÕES SOBRE O MODELO TÉCNICO QUE PRIORIZA O VALOR DE ENSINAR E AS METAS EM MATÉRIA DE EDUCAÇÃO
}

\author{
Vagner Neves Dias ${ }^{1}$
}

RESUMO: Constituído de um sistema complexo, o homem é uma máquina, com código genético único e com história pessoal de reforço e variável ambiental, cujo comportamento pode ser expresso em leis. Do mesmo modo, para existir uma sociedade estável, e nesse contexto eficiente, produtiva e competitiva, torna-se necessário uma avaliação mais aprofundada do comportamento humano no sentido de melhor gerir o homem (máquina) frente ao ambiente. Diante do contexto, surge então a escola behaviorista (fundamentada nas proposições teóricas da psicologia comportamental), que também influenciada pela decomposição do processo de trabalho, (a escola, sob a forma de funcionamento da fábrica), defende a tese de não ser possível a educação do homem. Um método de ensino que representa para a sociedade um meio de manter-se estável e para o indivíduo uma vantagem, uma vez que, torna-o muito mais produtivo e competitivo para o mercado. Contudo, para ocorrer um entendimento satisfatório acerca do método tecnicista de ensino é necessário que se compreenda inicialmente às três concepções de mundo e de homem, a saber: a cosmocêntrica, a teocêntrica e a antropocêntrica. Em epítome, a vida humana pode ser analisada em termos de atividades. Assim, se a educação tem como fim preparar o sujeito para a vida, este necessitará, portanto, ter desenvolvidas competências, habilidades, hábitos, atitudes e conhecimentos imprescindíveis para serem concebidas as atividades que a sociedade/mercado de trabalho tem solicitado

\section{PRESSUPOSTOS INTRODUTÓRIOS}

Constituído de um sistema complexo, o homem é uma máquina, com código genético único e com história pessoal de reforço e variável ambiental, cujo comportamento pode ser expresso em leis. Nesse diapasão, o ambiente quem determinará o homem (homem/individual), e sua racionalidade não será, portanto, totalmente livre, sendo, o seu

\footnotetext{
I Doutor em Ciências da Educação pela Universidad Interamericana - PY (2020). Mestre em Ciências da Educação pela Universidad Interamericana - PY (2018). Licenciado em Química pela Universidade Metropolitana de Santos (2017). Especialista em Metodologia de Ensino de Física e Química pela Faculdade Venda Nova do Imigrante (2015).Licenciado em Matemática através do Programa Especial de Formação de Docente pela Universidade Metropolitana de Santos (2012). Especialista em Educação Matemática com Novas Tecnologias pela Faculdade de Tecnologia e Ciências (2009). Graduado em Ciência da Computação pela Universidade Estadual do Sudoeste da Bahia (2007). Atualmente é professor de Matemática nas séries finais do Ensino Fundamental da Unidade Escolar Municipal Conveniada Gilberto Viana (Prefeitura de Itambé Bahia), e professor de Ciências e Matemática nas séries finais do Ensino Fundamental da Escola Municipal Naomar Soares de Alcântara (Prefeitura de Itororó - Bahia).
} 
pensamento, possível de ser identificado por meio de determinados processos comportamentais.

Para existir uma sociedade estável, e nesse contexto eficiente, produtiva e competitiva, torna-se necessário uma avaliação mais aprofundada do comportamento humano no sentido de melhor gerir o homem (máquina) frente ao ambiente. Aparece, assim, a preocupação em se radicalizar os métodos de ensino existentes na nova escola, pois, como menciona Luckesi (2011, p. 6I):

\begin{abstract}
A escola atua, assim, no aperfeiçoamento da ordem social vigente (o sistema capitalista), articulando-se diretamente com o sistema produtivo; para tanto, emprega a ciência da mudança de comportamento, ou seja, a tecnologia comportamental. Seu interesse imediato é o de produzir indivíduos "competentes" para o mercado de trabalho, transmitindo, eficientemente, informações precisas, objetivas e rápidas (LUCKESI, 20II, p. 6I).
\end{abstract}

Surge então a escola behaviorista (fundamentada nas proposições teóricas da psicologia comportamental), que também influenciada pela decomposição do processo de trabalho, (a escola, sob a forma de funcionamento da fábrica), defende a tese de não ser possível a educação do homem, mas o seu ensino por meio do estabelecimento de um comportamento padronizado e focado no futuro. Um método de ensino que representa para a sociedade um meio de manter-se estável e para o indivíduo uma vantagem, uma vez que o torna muito mais produtivo e competitivo para o mercado.

Contudo, para que ocorra um entendimento satisfatório acerca do método tecnicista de ensino é necessário que se compreenda inicialmente as três concepções de mundo e de homem (a cosmocêntrica, a teocêntrica e a antropocêntrica) alcançadas no decorrer da história, as quais apresentam características diferenciadas.

$\mathrm{Na}$ chamada concepção cosmocêntrica (criada pelos gregos no período mitológico que se inicia no século XI e estende-se até o século VI a.C.), "o homem se reconhecia como um ser submetido aos desígnios dos deuses, senhores do Cosmos e do destino humano" (TRANCOSO, 2014, p. I), ou seja, os homens nada mais eram que expectadores, os quais se assujeitavam às intempéries do Cosmo que tudo regia. 
Já na concepção teocêntrica (após oficializar-se o Cristianismo no Império Romano a partir do século IV d.C., perdurando-se até a chamada Revolução Científica iniciada no século XVI), Deus passa a ser o centro de tudo, ou seja, o conhecimento, a produção e demais fenômenos, necessitavam para se concretizar, de um Deus criador dos céus e da Terra (ARANHA, 1996).

Neste período, a classe burguesa que ganhava destaque e se apontava como uma nova classe social que buscava dentre outras coisas, a sua própria emancipação, passa a buscar uma nova posição do homem para com o universo, defendendo a possibilidade de este próprio passar a desvendar a Natureza.

Em 1543, a partir da descoberta de Copérnico (a qual negava a síntese aristotélica), o homem passa a ocupar uma nova posição em relação ao mundo, a ele mesmo e em relação a Deus. Inicia-se, assim, a Revolução Científica, período em que se deram mudanças profundas no mundo europeu (fruto do mercantilismo, que produziu uma verdadeira transição para o capitalismo e consequentemente para que fosse estabelecida uma nova organização econômica e social), outra concepção começou a ser gerada (a qual faz-se presente até os dias que seguem), que foi justamente a chamada concepção antropocêntrica, a qual torna o homem (com o auxílio da Ciência e das Técnicas), o centro de todas as coisas, o senhor da Natureza.

\footnotetext{
Em meados do século XVIII, a ciência moderna, saída da revolução científica do século XVI, caracteriza-se pelo crescimento da nova ordem econômica - o capitalismo - que, no século XIX, desencadeia o processo de industrialização e, com ele, a necessidade de respostas e soluções práticas no campo da técnica, um movimento que acarretou transformações sem precedentes na história da humanidade (TERRA, 2019, p. I).
}

Estabelece-se então, o modelo geral de racionalidade (a qual se desenvolveria posteriormente nos séculos subsequentes), que mesmo de forma acanhada no século XVIII, consegue atingir o campo das ciências sociais emergentes no século XIX. Acerca dessa nova racionalidade científica, considerada a base do pensamento moderno, para Santos (2010, p. 2I), trata-se de um modelo totalitário "na medida em que nega o caráter racional a todas as 
formas de conhecimento que não se pautarem pelos seus princípios epistemológicos e pelas suas regras metodológicas".

Assim, segundo Saviani (2008, p. II), mediante os pressupostos da neutralidade científica e fundamentada nas bases principiológicas da racionalidade, eficiência e produtividade, "a pedagogia tecnicista advogou a reordenação do processo educativo de maneira a torná-lo objetivo e operacional". Semelhante ao que aconteceu com o trabalho fabril, buscou-se "a objetivação do trabalho pedagógico".

A abordagem dos objetivos segundo Gimeno Sacristán (1986) está enraizada no movimento utilitário na educação, do início deste século nos Estados Unidos da América, em paralelo com o boom que a aplicação da abordagem taylorista está tendo sobre a indústria, mostrando seu potencial para aumentar a quantidade e qualidade de produção industrial. É neste momento em que a indústria como um modelo de organização da produção é tida como esquema-padrão na organização e desenvolvimento do currículo escolar.

Sobre isto, menciona Machado (1989, p.IoI) que a partir dos ideários da teoria behaviorista, "a educação passa a ser entendida como um elemento decisivo no desenvolvimento econômico do País”.

\footnotetext{
Embora a educação seja, em certa medida, uma atividade de consumo que oferece satisfação às pessoas no momento em que obtém um tipo de educação, é predominantemente uma atividade de investimento realizado para o fim de aquisição de capacitações futuras ou que incrementa rendimentos futuros da pessoa como um agente produtivo (MACHADO, i989, p. Ior).
}

O esquema ou movimento da pedagogia por objetivos não é perfeitamente homogêneo, é reforçado a partir do apoio que lhe deram várias abordagens filosóficas e científicas, mas em certa medida continua a ser um denominador comum, que é o que se quer dizer (SACRISTÁN, 1986). Procurou-se, assim, pautando-se em explicações teóricas advindas "da corrente filosófico-psicológica do behaviorismo, planejar a educação de modo a dotá-la de uma organização racional capaz de minimizar as interferências subjetivas" que de alguma maneira colocassem em situação de risco sua eficiência (SAVIANI, 2008, p. II). A evolução do paradigma da "racionalização científica", que é a pedagogia por objetivos, foi 
reforçada pela incorporação de novas ideias, mas apenas daquelas que poderiam favorecê-lo (SACRISTÁN, 1986).

Frente a tal entendimento:

[...] se na pedagogia tradicional a iniciativa cabia ao professor e se na pedagogia nova a iniciativa deslocou-se para o aluno, na pedagogia tecnicista o elemento principal passou a ser a organização racional dos meios, ocupando o professor e o aluno posição secundária (SAVIANI, 2008, p. 12).

Verifica-se, portanto, que a organização do processo foi substituída pela garantia da eficiência, na atuação do professor, vez que o eixo da proposta pedagógica na definição clara e precisa dos objetivos da educação e na oferta de ações para a sua realização, dependem essencialmente da figura do docente. Neste cenário, portanto, nasce a pedagogia tecnicista.

Sobre este assunto, convém mencionar que a pedagogia tecnicista tem a sua origem nos Estados Unidos ao final do século XX, chegando ao Brasil no fim da década de 1960 (durante o regime militar, por intermédio da implantação dos programas de desenvolvimento social e econômico), fundada na teoria behaviorista segundo a qual a sociedade deveria ser amoldada conforme a demanda industrial e tecnológica do período. $\mathrm{E}$ conforme mencionado anteriormente, a teoria behaviorista defende a tese de que o comportamento humano, por ser previsível, pode ser amoldado de maneira a se obter indivíduos "competentes" para o mercado de trabalho, neste contexto, mais ajustado à engrenagem capitalista.

O foco principal desta tendência pedagógica é produzir sujeitos capazes e eficientes para o desempenho de funções no mercado de trabalho. Ao valorizar as informações científicas, presentes nos manuais técnicos e de instrução, incumbe a escola de divulgar o modelo de produção capitalista, de forma a que o aluno internalize e seja bem treinado para inserir-se profissionalmente no sistema econômico vigente. [...] A prática pedagógica encontra-se voltada para a aplicação sistemática de princípios científicos comportamentais, cujo papel do professor é administrar as condições de transmissão de conteúdos, cabendo ao aluno executar o sistema instrucional previsto (AZEVEDO et al., 2013, p. 3).

Como mencionam Abreu, Mesquita e Anchieta (1997, p. I), entre a pedagogia por objetivos e o ensino tradicional está o objetivo educacional, pois, enquanto o ensino tradicional encontra-se relacionado aos valores apregoados pela sociedade na qual ele se desenvolva, a pedagogia por objetivos exprime "os níveis culturais a serem adquiridos na 
trajetória da educação formal”. Ou seja, se o aluno não consegue alcançar o mínimo cultural para aquela faixa educativa, o resultado não será alcançado e não haverá aprovação.

Neste âmbito, nota-se que o ensino encontra-se centrado na figura do docente, enquanto que ao aluno é cabível somente executar os comandos que lhe são fixados. Assim citam Abreu, Mesquita e Anchieta (1997, p. I), "o adulto, na concepção tradicional, é considerado como homem acabado, "pronto" e o aluno um "adulto em miniatura", que precisa ser atualizado".

A vida humana pode ser analisada em termos de atividades. Assim, se a educação tem como fim preparar o sujeito para a vida, este necessitará, portanto, ter desenvolvidas competências, habilidades, hábitos, atitudes e conhecimentos imprescindíveis para que sejam concebidas as atividades que a sociedade/mercado de trabalho tem solicitado, surgindo então a relevância em se notar o currículo deste indivíduo. Por esta razão, a pedagogia por objetivos tem seu foco na eficiência e na eficácia, visto que o currículo do discente deve ser capaz de apontar se este está apto para desenvolver as atividades demandadas pela sociedade, pois, conforme citam os autores:

O homem é considerado como inserido num mundo que irá conhecer através de informações que lhe serão fornecidas. É um receptor passivo até que, repleto das informações necessárias, pode repeti-las a outros que ainda não as possuam, assim como pode ser eficiente em sua profissão, quando de posse dessas informações e conteúdos (ABREU; MESQUITA; ANCHIETA, 1997, p. I).

Então, a figura do docente que não era valorizado torna-se indispensável, justamente porque este profissional passa a ser visualizado como o especialista, responsável por "transmitir" aos discentes verdades científicas incontestáveis.

No que diz respeito "à inteiração professor e aluno no interior da sala de aula, esta se dá de maneira bem formal, pois ambos devem cumprir papeis pré-definidos, bastando que cada um faça bem sua função" (AZEVEDO et al., 2013, p. 3). Percebe-se assim, que a escola tecnicista não valora a reflexão e criticidade nos alunos, mas, tão somente as suas metas pedagógicas.

Os conteúdos são transmitidos "conforme um sistema instrucional eficiente e efetivo em termos de resultados da aprendizagem; o aluno recebe, aprende e fixa as informações" (LUCKESI, 20II, p. 62). Desta forma, o trabalho docente fica resumido ao estabelecimento 
da ligação entre a verdade científica e o discente, por meio do emprego de metodologias instrucionais preestabelecidas.

Acerca desse aspecto formal referente ao relacionamento professor e aluno, Saviani (2008, p. 15) destaca que:

Nessas condições a pedagogia tecnicista acabou por contribuir para aumentar o caos no campo educativo, gerando tal nível de descontinuidade, de heterogeneidade e de fragmentação, que inviabiliza o trabalho pedagógico (SAVIANI, 2008, p. 15).

O formato behaviorista de ensino, ou tecnicista como assim é chamado, trabalha, portanto, com objetivos, e, para que estes sejam alcançados faz-se necessário que estímulos, reforços negativos e positivos sejam empregados, a fim de se alcançar frente à classe discente a resposta desejada.

\section{CONCLUSÃO}

Compreende-se então que o comportamento do sujeito é amoldado (através do controle da conduta individual), de maneira que estes passem a atuar de forma robótica conforme o cenário em que esteja inserido e conforme a demanda mercadológica.

É nesse cenário "que uma outra face do problema começa a merecer a atenção dos teóricos educacionais - a organização do processo de trabalho na escola" (MACHADO, I989, p. 104). O autor comenta ainda que realizando uma retrospectiva histórica, nota-se que a escola sempre esteve sob o controle da classe dominante, por meio do Estado. Nesse diapasão, ficam a olhos vistos as alterações na organização do processo de trabalho na escola, já que grande parte do controle de sua função é guiado por interesses dominantes.

\section{REFERÊNCIAS}

ABREU, Andréia Santos de; MESQUITA, Jam Alves; ANCHIETA, José de. Abordagens do Processo Ensino-Aprendizagem e o Professor. Brasília: Universidade Católica de Brasília, I997. Disponível em: 〈http://www.angelfire.com/ak2/jamalves/Abordagem.html〉. Acesso em: I6 fev. 202I.

ARANHA, Maria Lúcia de Arruda. Filosofia da Educação. São Paulo: Moderna, 1996. 
AZEVEDO, Antulio José de et al. A influência da pedagogia tecnicista na prática docente de uma escola de educação básica. Revista Científica Eletrônica de Pedagogia - ISSN: I678$300 X$ Ano XI - Número 2I - Janeiro de 2013.

LUCKESI, Cipriano Carlos. Filosofia da Educação. São Paulo: Cortez, 2011.

MACHADO Antônio Berto. Fábrica X Escola: Identidades e especificidades de uma relação algumas reflexões. Perspectiva; CED, Florianópolis, 7 (I3): IOI·II5, jul/dez. 1989.

SACRISTÁN, Gimeno J. La pedagogía por objetivos. Madrid: Ed. Morata, 1986.

SANTOS, Boaventura de Sousa. Um discurso sobre as ciências. São Paulo: Cortez, 2010.

SAVIANI, Demerval. Escola e Democracia. Edição Comemorativa. Campinas: Autores Associados, 2008.

TERRA, Márcia. O Behaviorismo em discussão. Disponível em: 〈http://www.unicamp.br/iel/site/alunos/publicacoes/textos/boooo8.htm>. Acesso em: o8 nov. 2019.

TRANCOSO, Alfeu. A concepção ecocêntrica. I8 de outubro de 2014. Disponível em: 〈https://espacoecologiconoar.com.br/a-concepcao-ecocentrica/〉. Acesso em: 28 mar. 202I. 